\title{
Symptomatic Cholelithiasis Patients Have Increased Pancreatic Cancer Risk- A Population Based Study
}

\section{Chi- Chih Wang}

Chung Shan Medical University Hospital https://orcid.org/0000-0002-8222-0503

\section{Ming-Hseng Tseng}

Chung Shan Medical University

\section{Sheng-Wen Wu}

Chung Shan Medical University Hospital

Tzu-Wei Yang

Chung Shan Medical University Hospital

Hsuan-Yi Chen

Chung Shan Medical University Hospital

Wen-Wei Sung

Chung Shan Medical University

\section{Chang-Cheng Su}

Chung Shan Medical University Hospital

\section{Yao-Tung Wang}

Chung Shan Medical University Hospital

Wei-Liang Chen

Chung Shan Medical University Hospital

Hsueh-Chou Lai

China Medical University

\section{Chun-Che Lin}

China Medical University

Ming-Chang Tsai ( $\nabla$ tsaimc1110@gmail.com)

https://orcid.org/0000-0002-7687-2329

\section{Research article}

Keywords: pancreatic cancer, endoscopic sphincterotomy, endoscopic papillary balloon dilatation, cholecystectomy

Posted Date: May 21st, 2020

DOI: https://doi.org/10.21203/rs.3.rs-28291/v1

License: @ (1) This work is licensed under a Creative Commons Attribution 4.0 International License. Read Full License

Version of Record: A version of this preprint was published at Journal of Gastroenterology and Hepatology on September 22nd, 2020. See the published version at https://doi.org/10.1111/jgh.15234. 


\section{Abstract}

Background :Pancreatic cancer is a fatal disease, andthe current risk factor survey is not suitable for sporadic pancreatic cancerthat lacks obvious family history orgenetic analysis data. The aim of the present study was to evaluate the roles of cholelithiasis and cholelithiasis treatmentson pancreatic cancer risk.

Methods: Symptomatic adult patients with an index admission ofcholelithiasis diagnosis were selectedfrom one million random samples of National Health Insurance Research Database (NHIRD)obtained between January 2005 andDecember 2009. Exclusion criteria included pancreatic cancer, benign neoplasm or anomalies of the pancreas, orendoscopic sphincterotomy/endoscopic papillary balloon dilatation (ES/EPBD), cholecystectomy (CCY) before 2004. The control group was matched in a 1:1 ratio for sex, age,chronic pancreatitis and pancreatic cystic disease The study group was divided into ES/EPBD, CCY, ES/EPBD\&CCY, and no-intervention groupsfor subsequent pancreatic cancer evaluation.

Results: Both the cholelithiasis group and the matched control group included 8,265 adult cases. The cholelithiasis group contained 86 (1.04\%) cases of diagnosed pancreatic cancer and the control group contained8 $(0.10 \%)$ cases $(p<0.001)$. Exclusion of pancreatic cancer cases diagnosed in the first 6 months still resulted in asignificantly higher pancreatic cancer rate in the cholelithiasis group $(0.22 \%)$ thanin the control group $(0.05 \%)$ $(\mathrm{p}=0.003)$. The subsequent pancreatic cancer rates weresimilar,at $0.17 \%, 0.11 \%, 0.26 \%$, and $0.29 \%$, in the ES/EPBD, CCY, ES/EPBD\&CCY, and nointervention groups, respectively.

Conclusion:Symptomatic cholelithiasis is a risk factor for pancreatic cancer, and the risk is similar regardless of the intervention of cholelithiasis.

Trial registration: This study was resisted on 23th August 2019 with registration number CS18136. The study design of this study is a retrospective database study.

\section{Background:}

Pancreatic cancer is a fatal disease, and surgical resection is possible only in a small portion of patients ${ }^{1}$. Even in the patients who can undergo pancreaticoduodenectomy, the five-year survival rate is less than 30 percent for patients with T1 tumors and only 10 percent for those with other resectable pancreatic cancers ${ }^{2}$. Today, R0 resection remains the only curative treatment and survival guarantee for pancreatic cancer ${ }^{2}$, but most symptomatic patients with pancreatic cancer have advanced, incurable disease at diagnosis. Therefore, R0 resection is a mission impossible, given the lack of an efficient screening policy.

The current screening policy focuses on familial pancreatic cancer, the presence of Peutz-Jeghers syndrome ${ }^{3}$, and individuals with a pancreatic cancer family history ${ }^{4}$. Pancreatic cancer is a genetic disease caused by inherited and acquired mutations in certain cancer-associated genes ${ }^{5}$ that lead normal pancreatic cells to form precursor lesions or invasive carcinomas. This recognition has led to a new classification system of pancreatic neoplasms ${ }^{6-8}$; however, the majority of newly diagnosed pancreatic cancer patients still cannot benefit from the current screening method.

Many risk factors have already been recognized in the existing literature, including hereditary risk factors ${ }^{9}$, germline mutations ${ }^{10}$, non-0 blood type ${ }^{11}$, diabetes mellitus $(\mathrm{DM})^{12-14}$, cigarette smoking ${ }^{15-18}$, obesity ${ }^{19}, 20$, physical inactivity ${ }^{21}, 22$, chronic hepatitis $\mathrm{B}(\mathrm{CHB})^{23,24}$, chronic hepatitis C $(\mathrm{CHC})^{23,25}$, and Helicobacter pylori (HP) infection ${ }^{26-28}$, but the best-known and strongest risks are chronic pancreatitis (CP) $)^{29,30}$ and pancreatic cystic disease $(P C D)^{31,32}$. A screening policy is hard to plan, except for $C P$ and $P C D$ patients, and gene analysis is too expensive for use as a screening method.

In our previous study, we found that patients with cholelithiasis have a higher cholangiocarcinoma risk when compared with the normal population, and this is especially true in patients who undergo endoscopic sphincterotomy (ES) or endoscopic papillary balloon dilatation (EPBD) $)^{33}$. The recognition that pancreatic juice and bile reflux in patients with pancreaticobiliary maljunction can lead to biliary malignancy ${ }^{34,35}$ led us to postulate a role for cholelithiasis, an increasing and high-prevalence disease worldwide, in pancreatic cancer. We conducted this retrospective database study to confirm whether symptomatic cholelithiasis or invasive interventions for cholelithiasis are risk factors for pancreatic cancer.

\section{Methods}

This study was a population-based retrospective cohort study based on Taiwan's NHIRD and the study methods have been described in detail in our previous studies ${ }^{33,36}$. This study was approved by the local Institutional Review Board (IRB) and the IRB waived the need for informed consent in this study. All authors have declared no conflicts of interest in this study.

\section{Study design}

Symptomatic patients more than 18 years old with an index admission with a diagnosis of cholelithiasis were selected from one million random samples of NHIRD data between January 2005 to December 2009 using Codes of International Statistical Classification of Diseases and Related Health Problems-9th Edition (ICD-9). We excluded patients who had undergone ES/EPBD, CCY, and lithotripsy in 2004. Patients with a diagnosis in 
2004 of pancreatic cancer, benign neoplasm of pancreas, or anomalies of pancreas were also excluded. A control group was selected by matching in a 1:1 ratio by sex, age, and the strong pancreatic cancer risk factors of CP and PCD. The control group cases were defined as individuals who had neither been diagnosed with cholelithiasis nor undergone a related medical procedure before January 2005 . The variables of follow-up time and known risk factors (such as $\mathrm{CHB}, \mathrm{CHC}$, HP infection, DM, ESRD, CP, and PCD) were compared between the two groups. We calculated the number of pancreatic cancer cases and rates of pancreatic cancer after index admission and 6 months after ES/EPBD, CCY, and ES/EPBD \& CCY intervention following index admission. We regarded pancreatic cancer that arose after the first 6 months as subsequent pancreatic cancer, which is recommended for the evaluation of procedure-related pancreatic cancer. However, the patients with pancreatic cancer diagnosed within 6 months after index admission for cholelithiasis were more likely to have been misdiagnosed or to have a concurrent malignancy rather than a subsequent pancreatic cancer. Detailed information about the study design is shown in Fig. 1. The ICD-9 codes for the diseases listed above and their procedure codes are provided in the supplementary table.

We divided the study group further into cases who had undergone ES/EPBD, CCY, or ES/EPBD \& CCY and cases who had not undergone any invasive intervention (the no-intervention group). The age, gender, previous known risk factors for pancreatic cancer, pancreatic cancer rate, and subsequent pancreatic cancer rate for these four subgroups are compared in Table 2 . The incidence of subsequent pancreatic cancer in these subgroups was also compared with that in the control group, and the cumulative risk of subsequent pancreatic cancer was calculated for each subgroup and the control group. 
Table 2

Comparison of patients with symptomatic cholelithiasis who underwent ES/EPBD, CCY, ES/EPBD \& CCY, or no intervention

\begin{tabular}{|c|c|c|c|c|c|c|c|c|c|}
\hline & \multicolumn{2}{|c|}{$\begin{array}{l}\text { ES/EPBD } \\
\mathrm{N}=572\end{array}$} & \multicolumn{2}{|c|}{$\begin{array}{l}\text { CCY } \\
N=3518\end{array}$} & \multicolumn{2}{|c|}{$\begin{array}{l}\text { ES/EPBD \& } \\
\text { CCY } \\
N=388\end{array}$} & \multicolumn{2}{|c|}{$\begin{array}{l}\begin{array}{l}\text { No } \\
\text { intervention }\end{array} \\
\mathrm{N}=3787\end{array}$} & \multirow[t]{2}{*}{$\begin{array}{l}P \\
\text { value }\end{array}$} \\
\hline & $\mathrm{N}$ & SD; $\%$ & $\mathrm{~N}$ & $\mathrm{SD} ; \%$ & $\mathrm{~N}$ & SD; \% & $\mathrm{N}$ & $\mathrm{SD} ; \%$ & \\
\hline Age, mean (SD) & 67.00 & 15.55 & 56.00 & 16.14 & 60.00 & 15.95 & 65.00 & 16.69 & $\dot{0} 001$ \\
\hline \multicolumn{10}{|l|}{ Age, years } \\
\hline $18-49$ & 89 & 15.56 & 1243 & 35.33 & 102 & 26.29 & 684 & 18.06 & \\
\hline $50-69$ & 191 & 33.39 & 1411 & 40.11 & 150 & 38.66 & 1286 & 33.96 & \\
\hline$>70$ & 292 & 51.05 & 864 & 24.56 & 136 & 35.05 & 1817 & 47.98 & \\
\hline Gender & & & & & & & & & $<.001$ \\
\hline Male & 314 & 54.90 & 1663 & 47.27 & 202 & 52.06 & 2057 & 54.32 & \\
\hline Female & 258 & 45.10 & 1855 & 52.73 & 186 & 47.94 & 1730 & 45.68 & \\
\hline Follow up time (month), mean (SD) & 42.42 & 22.12 & 48.87 & 19.55 & 51.70 & 13.32 & 38.25 & 1.01 & $\dot{0} 001$ \\
\hline \multicolumn{10}{|l|}{ Risk factors of pancreatic cancer } \\
\hline $\mathrm{CHB}$ & 58 & 10.14 & 305 & 8.67 & 28 & 7.22 & 382 & 10.09 & 0.077 \\
\hline $\mathrm{CHC}$ & 32 & 5.59 & 186 & 5.29 & 16 & 4.12 & 384 & 10.14 & $<.001$ \\
\hline HP & 8 & 1.40 & 47 & 1.34 & 9 & 2.32 & 67 & 1.77 & 0.297 \\
\hline DM & 198 & 34.62 & 951 & 27.03 & 112 & 28.87 & 1430 & 37.76 & $\begin{array}{l}< \\
0.001\end{array}$ \\
\hline ESRD & 19 & 3.32 & 71 & 2.02 & 2 & 0.52 & 159 & 4.20 & $<.001$ \\
\hline $\mathrm{CP}$ & 16 & 2.80 & 36 & 1.02 & 12 & 3.09 & 77 & 2.03 & $<.001$ \\
\hline PCD & 4 & 0.70 & 6 & 0.17 & 3 & 0.77 & 19 & 0.50 & 0.037 \\
\hline \multicolumn{10}{|l|}{ Pancreatic cancer } \\
\hline Number & 13 & 2.27 & 11 & 0.31 & 5 & 1.29 & 57 & 1.51 & $<.001$ \\
\hline Number after first 6 months & 1 & 0.17 & 4 & 0.11 & 1 & 0.26 & 11 & 0.29 & 0.415 \\
\hline Odds ratio & 1.54 & & 1 & & 2.27 & & 2.55 & & \\
\hline $\begin{array}{l}\text { Time to diagnosis of cancer (excluding case in first } 6 \\
\text { months), month }\end{array}$ & 8.09 & - & 59.41 & 15.56 & 40.5 & - & 29.70 & 21.98 & 0.091 \\
\hline
\end{tabular}

\section{Data processing and statistical analysis}

The NHIRD database, which includes one million nationwide representatives of the Taiwan population between 2004 and 2011 , was managed by employing Microsoft SQL Server 2008 R2 (Microsoft Corporation, Redmond, WA, USA) and using the SQL programming language for data queries and data processing. Data obtained from the study were compared with the chi-square $\left(\chi^{2}\right)$ test for categorical variables, the t-test, or one-way ANOVA (Analysis of Variance) for continuous variables, and the log rank (Mantel-Cox) test for survival curves. A two-tailed P-value of 0.05 was considered statistically significant.

Statistical analysis was done using OpenEpi: open source epidemiologic statistics for public health, version $3.01^{37}$. Kaplan-Meier survival analyses were conducted using SPSS version 19. Person-time analyses were done using OpenEpi version 3.01.

\section{Results:}


In total, 8,440 adult symptomatic cholelithiasis admission cases were selected from one million random samples of NHIRD data between January 2005 and December 2009. Cases $(n=101)$ that had undergone ES/EPBD, CCY, or lithotripsy in 2004 or before the diagnosis of cholelithiasis $(n=$ $101)$ and cases $(n=74)$ diagnosed with pancreatic cancer, benign neoplasm of pancreas, or anomalies of the pancreas before index admission were excluded. We selected 8,265 cholelithiasis patients who had none of these exclusion criteria from January 2005 to December 2009 as the study group. The control group was drawn at a 1:1 ratio from cases without cholelithiasis but matching the study group in age, gender, and CP and PCD risk. The 8,265 patients in the cholelithiasis group had a mean age of $61 \pm 16.98$ years, and those in the control group had a mean age of $61 \pm$ 17.29 years. Males accounted for $51.25 \%$ of the subjects in both the cholelithiasis and control groups.

Our use of age, gender, and CP and PCD risk to establish the control group without cholelithiasis minimized the risk factors of pancreatic cancer, which could confound the results. The age distribution was also similar in both groups. The cholelithiasis group had significantly higher pancreatic cancer risk factors, such as CHB (9.35\% vs. $2.47 \%)$, CHC (7.48\% vs. $2.06 \%)$, HP infection (1.58\% vs. $0.59 \%)$, DM (32.56\% vs. $17.29 \%)$, and end stage renal disease (ESRD; $3.04 \%$ vs. $1.06 \%$ ). Some of these risk factors are also risk factors for cholelithiasis ${ }^{38}$.

The cholelithiasis group contained $86(1.04 \%)$ cases diagnosed as pancreatic cancer, while the control group had $8(0.10 \%)(p<0.001)$. Exclusion of pancreatic cancer cases occurring in the first 6 months after index admission still revealed a significantly higher subsequent pancreatic cancer rate in the cholelithiasis group $(0.22 \%)$ than in the control group $(0.05 \%)(p=0.003)$. These comparisons are shown in Table 1 . The cumulative risks of cholelithiasis group and control group for pancreatic cancer (Panel A) and subsequent pancreatic cancer (Panel B) are demonstrated in Fig. 2. 
Table 1

Demographic data of the study and control group

\begin{tabular}{|c|c|c|c|c|c|}
\hline & \multirow{2}{*}{\multicolumn{2}{|c|}{$\begin{array}{l}\text { Cholelithiasis group } \\
\mathrm{N}=8265\end{array}$}} & \multirow{2}{*}{\multicolumn{2}{|c|}{$\begin{array}{l}\text { Control group } \\
\mathrm{N}=8265\end{array}$}} & \multirow[t]{3}{*}{ p value } \\
\hline & & & & & \\
\hline & $\mathbf{N}$ & SD; \% & $\mathbf{N}$ & SD; \% & \\
\hline Age, mean (SD) & 61.00 & 16.98 & 61.00 & 17.29 & 1.000 \\
\hline Age, years & & & & & 0.364 \\
\hline $18-49$ & 2118 & 25.63 & 2197 & 26.58 & \\
\hline $50-69$ & 3038 & 36.76 & 3013 & 36.45 & \\
\hline$>70$ & 3109 & 37.62 & 3055 & 36.96 & \\
\hline Gender & & & & & 1.000 \\
\hline Male & 4236 & 51.25 & 4236 & 51.25 & \\
\hline Female & 4029 & 48.75 & 4029 & 48.75 & \\
\hline Follow up time (months), mean (SD) & 43.69 & 22.75 & 51.30 & 18.63 & $<0.001$ \\
\hline \multicolumn{6}{|l|}{ Risk factors for pancreatic cancer } \\
\hline $\mathrm{CHB}$ & 773 & 9.35 & 204 & 2.47 & $<0.001$ \\
\hline $\mathrm{CHC}$ & 618 & 7.48 & 170 & 2.06 & $<0.001$ \\
\hline HP & 131 & 1.58 & 49 & 0.59 & $<0.001$ \\
\hline DM & 2691 & 32.56 & 1429 & 17.29 & $<0.001$ \\
\hline ESRD & 251 & 3.04 & 88 & 1.06 & $<0.001$ \\
\hline $\mathrm{CP}$ & 141 & 1.71 & 141 & 1.71 & 1.000 \\
\hline PCD & 32 & 0.39 & 32 & 0.39 & 1.000 \\
\hline \multicolumn{6}{|l|}{ Pancreatic cancer } \\
\hline Number (rate) & 86 & 1.04 & 8 & 0.10 & $<0.001$ \\
\hline Follow up time (months), mean (SD) & 17.11 & 23.35 & 19.93 & 19.15 & $<0.001$ \\
\hline \multicolumn{6}{|l|}{ Pancreatic cancer after first 6 months } \\
\hline Number (rate) & 18 & 0.22 & 4 & 0.05 & 0.003 \\
\hline Follow up time (months), mean (SD) & 34.63 & 23.77 & 35.93 & 12.94 & $<0.001$ \\
\hline
\end{tabular}

\section{Cholelithiasis cases that underwent ES/EPBD, CCY, ES/EPBD \& CCY, or no intervention}

Of the 8,265 patients with index cholelithiasis, 572 underwent ES/EPBD, 3,518 underwent CCY, 388 underwent ES/EPBD \& CCY, and 3,787 received supportive care without further intervention. The average age was $67.00 \pm 15.55$ years in the ES/EPBD group, $56.00 \pm 16.14$ years in the CCY group, $60.00 \pm 15.95$ years in the ES/EPBD \& CCY group, and $65.00 \pm 16.69$ years in the no-intervention group. Patients were statistically younger in the CCY and ES/EPBD \& CCY groups, and these groups had a higher proportion of patients aged 18-49 years. The follow-up time was the shortest for the no-intervention group because of the clinical comorbidity condition in this group. The CCY group had the highest proportion of females, at $52.73 \%$ vs. $47.27 \%$, and we believe the higher prevalence of gallbladder stones in females can explain this result.

Evaluation of the subsequent pancreatic cancer risk revealed one subsequent pancreatic cancer in the ES/EPBD group, four in the CCY group, one in the ES/EPBD \& CCY group, and 11 in the no-intervention group. Although the pancreatic cancer risk differed significantly among these groups, the subsequent pancreatic cancer rates were similar, at $0.17 \%, 0.11 \%, 0.26 \%$, and $0.29 \%$ in the ES/EPBD, CCY, ES/EPBD \& CCY, and no-intervention groups, respectively. The cumulative subsequent pancreatic cancer risks, shown in Fig. 3 , are similar in all four groups ( $p=0.492)$. 
Evaluation of the previous pancreatic cancer risk factors indicated that CHB and HP infection were not statistically different in these groups. The no-intervention group had a higher proportion of patients having $\mathrm{CHC}, \mathrm{DM}$, and ESRD, whereas patients with $\mathrm{CP}$ and PCD were more frequent in the ES/EPBD (2.80\% and $0.70 \%$, respectively) or ES/EPBD \& CCY (3.09\% and $0.77 \%$, respectively) groups. Detailed information is shown in Table 2 .

\section{The incidence of subsequent pancreatic cancer}

This was a retrospective study; therefore, the subsequent pancreatic risks may be confounded by different follow-up times. The incidences of pancreatic cancer after the first 6 months (henceforth, subsequent pancreatic cancer) between patients who underwent ES/EPBD, CCY, ES/EPBD \& $\mathrm{CCY}$, no intervention for cholelithiasis, and the control group were compared using the incidence rate per 1000 person-years. The ES/EPBD group showed an incidence of subsequent pancreatic cancer of $0.495(0.025-2.439)$ per 1000 person-years, which is 4 -fold greater than the incidence in the control group, although this difference did not meet statistical significance. The incidence of subsequent pancreatic cancer was 0.070 ( $0.003-$ $0.344)$ per 1000 person-years in the CCY group $(p=0.223), 0.598(0.030-2.950)$ in the ES/EPBD \& CCY group $(p=0.225)$, and $0.911(0.479-1.584)$ in the no-intervention group $(\mathrm{p}<0.001)$. The incidence of subsequent pancreatic cancer in the no-intervention group was 9 -fold higher than in the control group, and this was the only subgroup that had a subsequent pancreatic cancer incidence, at 0.911 (0.479-1.584) per 1000 person-years, that differed significantly from the incidence in the normal population, at $0.113(0.036-0.273)$ per 1000 person-years $(p<0.001)$. The incidence of subsequent pancreatic cancer was even higher for females in the no-intervention group, at $1.216(0.532-2.404)$ per 1000 person-years. All these data are shown in Table 3. 
Table 3

Incidence of pancreatic cancer amount patient with cholelithiasis underwent ES/EPBD, cholecystectomy, ES/EPBD \& cholecystectomy or no intervention compared with normal population (excluding pancreatic cancer in the initial 6 months)

\begin{tabular}{|c|c|c|c|c|c|c|c|c|c|}
\hline Variables & $\begin{array}{l}\text { Person- } \\
\text { years at } \\
\text { risk in } \\
\text { study } \\
\text { cohort }\end{array}$ & $\begin{array}{l}\text { Person- } \\
\text { years at } \\
\text { risk in } \\
\text { control } \\
\text { cohort }\end{array}$ & $\begin{array}{l}\text { No. of } \\
\text { observed } \\
\text { cases of } \\
\text { pancreatic } \\
\text { cancer in } \\
\text { study } \\
\text { cohort }\end{array}$ & $\begin{array}{l}\text { No. of } \\
\text { observed } \\
\text { cases of } \\
\text { pancreatic } \\
\text { cancer in } \\
\text { control } \\
\text { cohort }\end{array}$ & $\begin{array}{l}\text { Incidence } \\
\text { proportion } \\
\text { of } \\
\text { pancreatic } \\
\text { cancer in } \\
\text { study } \\
\text { cohort }\end{array}$ & $\begin{array}{l}\text { Incidence } \\
\text { proportion } \\
\text { of } \\
\text { pancreatic } \\
\text { cancer in } \\
\text { control } \\
\text { cohort }\end{array}$ & $\begin{array}{l}\text { Incidence } \\
\text { rate/ } 1,000 \\
\text { person- } \\
\text { years ( } 95 \% \\
\mathrm{Cl}) \text { in study } \\
\text { cohort }\end{array}$ & $\begin{array}{l}\text { Incidence } \\
\text { rate/1,000 } \\
\text { person- } \\
\text { years ( } 95 \% \\
\mathrm{Cl}) \text { in } \\
\text { control } \\
\text { cohort }\end{array}$ & $\begin{array}{l}P \\
\text { value }\end{array}$ \\
\hline \multicolumn{10}{|l|}{ ES/EPBD } \\
\hline Total & 2022.069 & 35330.286 & 1 & 4 & 0.175 & 0.048 & $\begin{array}{l}0.495 \\
(0.025- \\
2.439)\end{array}$ & $\begin{array}{l}0.113(0.036- \\
0.273)\end{array}$ & 0.506 \\
\hline \multicolumn{10}{|l|}{ Gender } \\
\hline Male & 1095.811 & 17987.821 & 0 & 3 & 0 & 0.071 & $\begin{array}{l}0.000(0.000- \\
0.000)\end{array}$ & $\begin{array}{l}0.167(0.042- \\
0.454)\end{array}$ & $>0.999$ \\
\hline Female & 926.258 & 17342.465 & 1 & 1 & 0.388 & 0.025 & $\begin{array}{l}1.080 \\
(0.054- \\
5.325)\end{array}$ & $\begin{array}{l}0.058(0.003- \\
0.284)\end{array}$ & 0.101 \\
\hline \multicolumn{10}{|c|}{ Cholecystectomy } \\
\hline Total & 14325.789 & 35330.286 & 4 & 4 & 0.114 & 0.048 & $\begin{array}{l}0.070(0.003- \\
0.344)\end{array}$ & $\begin{array}{l}0.113(0.036- \\
0.273)\end{array}$ & 0.223 \\
\hline \multicolumn{10}{|l|}{ Gender } \\
\hline Male & 6609.131 & 17987.821 & 2 & 3 & 0.120 & 0.071 & $\begin{array}{l}0.303(0.051- \\
1.000)\end{array}$ & $\begin{array}{l}0.167(0.042- \\
0.454)\end{array}$ & 0.531 \\
\hline Female & 7716.658 & 17342.465 & 2 & 1 & 0.108 & 0.025 & $\begin{array}{l}0.259(0.043- \\
0.856)\end{array}$ & $\begin{array}{l}0.058(0.003- \\
0.284)\end{array}$ & 0.255 \\
\hline \multicolumn{10}{|c|}{$\begin{array}{l}\text { ES/EPBD \& } \\
\text { Cholecystectomy }\end{array}$} \\
\hline Total & 1671.559 & 35330.286 & 1 & 4 & 0.258 & 0.048 & $\begin{array}{l}0.598(0.030- \\
2.950)\end{array}$ & $\begin{array}{l}0.113(0.036- \\
0.273)\end{array}$ & 0.225 \\
\hline \multicolumn{10}{|l|}{ Gender } \\
\hline Male & 842.399 & 17987.821 & 0 & 3 & 0 & 0.071 & $\begin{array}{l}0.000(0.000- \\
0.000)\end{array}$ & $\begin{array}{l}0.167(0.042- \\
0.454)\end{array}$ & 0.872 \\
\hline Female & 829.160 & 17342.465 & 1 & 1 & 0.538 & 0.025 & $\begin{array}{l}1.206(0.060- \\
5.948)\end{array}$ & $\begin{array}{l}0.058(0.003- \\
0.284)\end{array}$ & 0.091 \\
\hline \multicolumn{10}{|c|}{ No intervention } \\
\hline Total & 12069.737 & 35330.286 & 11 & 4 & 0.290 & 0.048 & $\begin{array}{l}0.911 \\
(0.479- \\
1.584)\end{array}$ & $\begin{array}{l}0.113(0.036- \\
0.273)\end{array}$ & $<0.001$ \\
\hline \multicolumn{10}{|l|}{ Gender } \\
\hline Male & 6310.964 & 17987.821 & 4 & 3 & 0.194 & 0.071 & $\begin{array}{l}0.634(0.201- \\
1.529)\end{array}$ & $\begin{array}{l}0.167(0.042- \\
0.454)\end{array}$ & 0.095 \\
\hline Female & 5758.773 & 17342.465 & 7 & 1 & 0.405 & 0.025 & $\begin{array}{l}1.216(0.532- \\
2.404)\end{array}$ & $\begin{array}{l}0.058(0.003- \\
0.284)\end{array}$ & $<0.001$ \\
\hline
\end{tabular}

\section{Discussion:}

The current surveillance and screening suggestions for pancreatic cancer are difficult to carry out in clinical practice. For this reason, we have attempted to identify a high risk group without resorting to complicated and costly genetic analysis. We noted that many well-known risk factors for cholangiocarcinoma, such as $\mathrm{CHB}, \mathrm{CHC}^{39}, 40, \mathrm{DM}^{41,42}$, and $\mathrm{HP}$ infection ${ }^{43,44}$, are coincidentally also risk factors for pancreatic cancer. We also recognized that cholelithiasis is an important risk factor for bile duct cancer ${ }^{45}, 46$; therefore, we explored the possible relationship between cholelithiasis and pancreatic cancer and the influences of invasive bile duct procedures on the subsequent pancreatic cancer rate. As reported here, we found that the pancreatic cancer rate is significantly higher in the cholelithiasis group than in the control group after adjustment for CP and PCD (1.04\% vs. $0.10 \%, p<0.001$ ). 
Because the previous known risk factors of pancreatic cancer, such as $\mathrm{CHB}, \mathrm{CHC}, \mathrm{DM}, \mathrm{HP}$, are higher in cholelithiasis group, the increased pancreatic cancer risk may be confound by these factors. We performed multivariate analysis between these risk factors to isolate the most important risk factors for pancreatic cancer and it revealed old age, symptomatic cholelithiasis (Odds ratio 9.971 [4.793-20.744], $\mathrm{p}<0.001$ ) and DM to be significant risk factors of pancreatic cancer after CP and PCD been excluded by our study design. Symptomatic cholelithiasis is the most important risk factors of pancreatic cancer in both cholelithiasis and control group, the details were shown in Table 4.

Table 4

Multivariate analysis of risk factors for pancreatic cancer

\begin{tabular}{|c|c|c|c|c|c|c|}
\hline & \multicolumn{2}{|c|}{$\begin{array}{l}\text { Pancreatic cancer } \\
\mathrm{N}=94\end{array}$} & \multicolumn{2}{|c|}{$\begin{array}{l}\text { No pancreatic cancer } \\
\mathrm{N}=16,436\end{array}$} & \multirow[t]{2}{*}{ OR (95\% Cl) } & \multirow[t]{2}{*}{$p$ value } \\
\hline & $\mathrm{N}$ & SD; \% & $\mathrm{N}$ & $\mathrm{SD} ; \%$ & & \\
\hline Age, mean (SD) & 70.09 & 15.02 & 61.48 & 17.14 & $1.033(1.019-1.048)$ & $<0.001$ \\
\hline \multicolumn{7}{|l|}{ Gender } \\
\hline Male & 44 & $46.81 \%$ & 8,428 & $51.28 \%$ & $0.832(0.553-1.253)$ & 0.380 \\
\hline Cholelithiasis & 86 & $91.49 \%$ & 8,179 & $49.76 \%$ & $9.971(4.793-20.744)$ & $<0.001$ \\
\hline $\mathrm{CHB}$ & 10 & $10.64 \%$ & 967 & $5.88 \%$ & $1.724(0.876-3.394)$ & 0.115 \\
\hline $\mathrm{CHC}$ & 4 & $4.26 \%$ & 784 & $4.77 \%$ & $0.525(0.190-1.450)$ & 0.214 \\
\hline $\mathrm{HP}$ & 3 & $3.19 \%$ & 177 & $1.08 \%$ & 2.465 (0.765-7.939) & 0.131 \\
\hline DM & 42 & $44.68 \%$ & 4,078 & $24.81 \%$ & $1.532(1.010-2.325)$ & 0.045 \\
\hline ESRD & 1 & $1.06 \%$ & 337 & $2.05 \%$ & $0.291(0.040-2.109)$ & 0.222 \\
\hline
\end{tabular}

In the second part of this study, we defined pancreatic cancer newly diagnosed at least 6 months after index admission as subsequent pancreatic cancer as a way to exclude the possibility of misdiagnosis or concurrent pancreatic cancer during cholelithiasis treatment. We evaluated the effect of invasive bile duct interventions, like ES/EPBD, CCY, and ES/EPBD \& CCY, on the subsequent pancreatic cancer risk. Comparisons between patients with cholelithiasis and the control group revealed a significantly higher subsequent pancreatic cancer risk in the patients with cholelithiasis $(0.22 \%$ vs. $0.05 \%, p=0.003)$. Comparisons of the four subgroups in the cholelithiasis group revealed that the subsequent pancreatic cancer risk was only slightly higher in the no-intervention group, but the difference was not statistically significant. The different invasive procedures for cholelithiasis treatment therefore do not appear to affect the subsequent pancreatic cancer risk, according to our analysis.

Our study had several limitations. One was that this was a retrospective national cohort database study, so no laboratory data results or clinical images are presented. We can only rely on the diagnosis made by clinical physicians and cannot re-evaluate these patients to get better diagnoses. This is partly why we excluded pancreatic cancer diagnosed in the first 6 months after index admission in our analysis of the procedure-related pancreatic cancer rates. However, the innate character of a national cohort database means that this selection also avoids patient loss at follow-up and missed diagnoses of pancreatic cancer, even in patients who underwent treatment at different hospitals. Another limitation is that the total pancreatic cancer occurrence was 86 patients in the cholelithiasis group and 8 patients in control group, but the subsequent pancreatic cancer occurrence was only one patient in the ES/EPBD and ES/EPBD \& CCY groups, which makes any statistical significance difficult to detect. Further larger scaled retrospective or prospective studies are needed to evaluate the procedure-related subsequent pancreatic cancer risks. A third limitation is that the cholelithiasis group had higher proportions of some pancreatic cancer risk factors, such as $\mathrm{CHB}, \mathrm{CHC}, \mathrm{HP}$, and DM. Although CHC and $\mathrm{ESRD}^{47}$ can be explained by common risk factors of cholelithiasis itself, $\mathrm{CHB}, \mathrm{HP}$, and DM may slightly affect the pancreatic cancer risk between the cholelithiasis and control groups. For this reason, we have done the multivariate analysis in these risk factors of pancreatic cancer.

\section{Conclusions :}

Symptomatic cholelithiasis patients have increased pancreatic cancer risk than control group, but the subsequent pancreatic cancer risk is similar regardless of intervention (ES/EPBD, CCY, ES/EPBD \& CCY, or no invasive intervention) in patients with cholelithiasis.

\section{Abbreviations}

Endoscopic sphincterotomy

ES

Endoscopic papillary balloon dilatation

EPBD 
National Health Insurance Research Database

NHIRD

Cholecystectomy

CCY

Diabetes mellitus

DM

Chronic hepatitis B

$\mathrm{CHB}$

Chronic hepatitis $\mathrm{C}$

$\mathrm{CHC}$

Helicobacter pylori

HP

Chronic pancreatitis

CP

Pancreatic cystic disease

PCD

Institutional Review Board

IRB

Codes of International Statistical Classification of Diseases and Related Health Problems-9th Edition

ICD-9

End stage renal disease

ESRD

Standard deviation

SD

Minimum basic salary

MBS

Declarations

\section{Ethics approval and consent to participate}

This database study was approved by the local IRB of Chung Shan Medical University Hospital and the IRB waived the need for informed consent in this study.

Committee's reference number: CS18136

We received administrative permission to access and use these data from National Health Insurance Administration Ministry of Health and Welfare of Taiwan.

\section{Consent for publication}

There is no identifying images, other personal or clinical details of participants presented in our study. Because of the design of this de-link database article, consent to publish is not applicable to my manuscript.

\section{Availability of data and materials}

The datasets generated and analysed during the current study are not publicly available due to they come from NHIRD but are partially available from the corresponding author on reasonable request.

\section{Competing interests statement:}

The authors declare that they have no any conflict of interest.

\section{Funding:}

This work was supported by grants fromChung Shan Medical University HospitalResearch Program ( CSH-2013-C-032). 
We purchase the right to access representative samples in NHIRD by Chun-Che Lin through the research program of CSMUH.

\section{Author contributions statement:}

Conception and design: C-C W, M-H T,W-W S

Acquisition of data: M-H T, S-W W, W-L C

Analysis and interpretation of data: C-C W, Y-T W, S-W W

Drafting of the manuscript: C-C W, T-W Y, H-Y C

Critical revision of the manuscript: M-C T, H-C L,C-C L

Statistical analysis: M-C T,W-W S,C-C S

Supervision: M-C T

All authors have read and approved the manuscript.

\section{Acknowledgements}

Not Applicable

\section{Refereneces}

1. [1] Bilimoria KY, Bentrem DJ, Ko CY, Stewart AK, Winchester DP, Talamonti MS. National failure to operate on early stage pancreatic cancer. Ann Surg. 2007; 246: 173-80.

2. [2] Allen PJ, Kuk D, Castillo CF, et al. Multi-institutional Validation Study of the American Joint Commission on Cancer (8th Edition) Changes for T and N Staging in Patients With Pancreatic Adenocarcinoma. Ann Surg. 2017; 265: 185-91.

3. [3] Canto MI, Harinck F, Hruban RH, et al. International Cancer of the Pancreas Screening (CAPS) Consortium summit on the management of patients with increased risk for familial pancreatic cancer. Gut. 2013; 62: 339-47.

4. [4] Schneider R, Slater EP, Sina M, et al. German national case collection for familial pancreatic cancer (FaPaCa): ten years experience. Fam Cancer. 2011; 10: 323-30.

5. [5] Hruban RH, Canto MI, Griffin C, et al. Treatment of familial pancreatic cancer and its precursors. Curr Treat Options Gastroenterol. 2005; 8: $365-75$.

6. [6] Hruban RH, Goggins M, Parsons J, Kern SE. Progression model for pancreatic cancer. Clin Cancer Res. 2000; 6: $2969-72$.

7. [7] Wilentz RE, lacobuzio-Donahue CA, Argani P, et al. Loss of expression of Dpc4 in pancreatic intraepithelial neoplasia: evidence that DPC4 inactivation occurs late in neoplastic progression. Cancer Res. 2000; 60: 2002-6.

8. [8] Basturk O, Hong SM, Wood LD, et al. A Revised Classification System and Recommendations From the Baltimore Consensus Meeting for Neoplastic Precursor Lesions in the Pancreas. Am J Surg Pathol. 2015; 39: 1730-41.

9. [9] Klein AP, Hruban RH, Brune KA, Petersen GM, Goggins M. Familial pancreatic cancer. Cancer J. 2001 ; 7: $266-73$.

10. [10] Shindo K, Yu J, Suenaga M, et al. Deleterious Germline Mutations in Patients With Apparently Sporadic Pancreatic Adenocarcinoma. J Clin Oncol. 2017; 35: 3382-90.

11. [11] Wolpin BM, Chan AT, Hartge P, et al. ABO blood group and the risk of pancreatic cancer. J Natl Cancer Inst. 2009; 101: 424-31.

12. [12] Batabyal P, Vander Hoorn S, Christophi C, Nikfarjam M. Association of diabetes mellitus and pancreatic adenocarcinoma: a metaanalysis of 88 studies. Ann Surg Oncol. 2014; 21: 2453-62.

13. [13] Bosetti C, Rosato V, Li D, et al. Diabetes, antidiabetic medications, and pancreatic cancer risk: an analysis from the International Pancreatic Cancer Case-Control Consortium. Ann Oncol. 2014; 25: 2065-72.

14. [14] Aggarwal G, Kamada P, Chari ST. Prevalence of diabetes mellitus in pancreatic cancer compared to common cancers. Pancreas. 2013; 42: 198-201.

15. [15] Farrow DC, Davis S. Risk of pancreatic cancer in relation to medical history and the use of tobacco, alcohol and coffee. Int $J$ Cancer. 1990; 45: 816-20.

16. [16] Lynch SM, Vrieling A, Lubin JH, et al. Cigarette smoking and pancreatic cancer: a pooled analysis from the pancreatic cancer cohort consortium. Am J Epidemiol. 2009; 170: 403-13. 
17. [17] Bosetti C, Lucenteforte E, Silverman DT, et al. Cigarette smoking and pancreatic cancer: an analysis from the International Pancreatic Cancer Case-Control Consortium (Panc4). Ann Oncol. 2012; 23: 1880-8.

18. [18] Duell EJ, Holly EA, Bracci PM, Liu M, Wiencke JK, Kelsey KT. A population-based, case-control study of polymorphisms in carcinogenmetabolizing genes, smoking, and pancreatic adenocarcinoma risk. J Natl Cancer Inst. 2002; 94: 297-306.

19. [19] Carreras-Torres R, Johansson M, Gaborieau V, et al. The Role of Obesity, Type 2 Diabetes, and Metabolic Factors in Pancreatic Cancer: A Mendelian Randomization Study. J Natl Cancer Inst. 2017; 109.

20. [20] Aune D, Greenwood DC, Chan DS, et al. Body mass index, abdominal fatness and pancreatic cancer risk: a systematic review and nonlinear dose-response meta-analysis of prospective studies. Ann Oncol. 2012; 23: 843-52.

21. [21] Michaud DS, Giovannucci E, Willett WC, Colditz GA, Stampfer MJ, Fuchs CS. Physical activity, obesity, height, and the risk of pancreatic cancer. JAMA. 2001; 286: 921-9.

22. [22] Lauby-Secretan B, Scoccianti C, Loomis D, et al. Body Fatness and Cancer-Viewpoint of the IARC Working Group. N Engl J Med. 2016; 375: 794-8.

23. [23] Hassan MM, Li D, El-Deeb AS, et al. Association between hepatitis B virus and pancreatic cancer. J Clin Oncol. 2008; 26: $4557-62$.

24. [24] Huang J, Magnusson M, Torner A, Ye W, Duberg AS. Risk of pancreatic cancer among individuals with hepatitis $C$ or hepatitis $B$ virus infection: a nationwide study in Sweden. Br J Cancer. 2013; 109: 2917-23.

25. [25] Mahale P, Torres HA, Kramer JR, et al. Hepatitis C virus infection and the risk of cancer among elderly US adults: A registry-based casecontrol study. Cancer. 2017; 123: 1202-11.

26. [26] Stolzenberg-Solomon RZ, Blaser MJ, Limburg PJ, et al. Helicobacter pylori seropositivity as a risk factor for pancreatic cancer. $J$ Natl Cancer Inst. 2001; 93: 937-41.

27. [27] Raderer M, Wrba F, Kornek G, et al. Association between Helicobacter pylori infection and pancreatic cancer. Oncology. 1998; 55: 16-9.

28. [28] Trikudanathan G, Philip A, Dasanu CA, Baker WL. Association between Helicobacter pylori infection and pancreatic cancer. A cumulative meta-analysis. JOP. 2011; 12: 26-31.

29. [29] Duell EJ, Lucenteforte $\mathrm{E}$, Olson $\mathrm{SH}$, et al. Pancreatitis and pancreatic cancer risk: a pooled analysis in the International Pancreatic Cancer Case-Control Consortium (PanC4). Ann Oncol. 2012; 23: 2964-70.

30. [30] Bang UC, Benfield T, Hyldstrup L, Bendtsen F, Beck Jensen JE. Mortality, cancer, and comorbidities associated with chronic pancreatitis: a Danish nationwide matched-cohort study. Gastroenterology. 2014; 146: 989-94.

31. [31] Pergolini I, Sahora K, Ferrone CR, et al. Long-term Risk of Pancreatic Malignancy in Patients With Branch Duct Intraductal Papillary Mucinous Neoplasm in a Referral Center. Gastroenterology. 2017; 153: 1284-94 e1.

32. [32] Tanaka M. Controversies in the management of pancreatic IPMN. Nat Rev Gastroenterol Hepatol. 2011 ; 8: 56-60.

33. [33] Wang CC, Tsai MC, Sung WW, et al. Risk of cholangiocarcinoma in patients undergoing therapeutic endoscopic retrograde cholangiopancreatography or cholecystectomy: A population based study. World J Gastrointest Oncol. 2019; 11: $238-49$.

34. [34] Kamisawa T, Kuruma S, Chiba K, Tabata T, Koizumi S, Kikuyama M. Biliary carcinogenesis in pancreaticobiliary maljunction. J Gastroenterol. 2017; 52: 158-63.

35. [35] Kamisawa T, Kuruma S, Tabata T, et al. Pancreaticobiliary maljunction and biliary cancer. J Gastroenterol. 2015; 50: 273-9.

36. [36] Wang CC, Tsai MC, Wang YT, et al. Role of Cholecystectomy in Choledocholithiasis Patients Underwent Endoscopic Retrograde Cholangiopancreatography. Sci Rep. 2019; 9: 2168.

37. [37] Dean AG SK, Soe MM. OpenEpi: Open Source Epidemiologic Statistics for Public Health, Version. updated 2013/04/06, accessed 2018/01/06.

38. [38] Acalovschi M, Buzas C, Radu C, Grigorescu M. Hepatitis C virus infection is a risk factor for gallstone disease: a prospective hospitalbased study of patients with chronic viral C hepatitis. $J$ Viral Hepat. 2009; 16: 860-6.

39. [39] Shin HR, Lee CU, Park HJ, et al. Hepatitis B and C virus, Clonorchis sinensis for the risk of liver cancer: a case-control study in Pusan, Korea. Int J Epidemiol. 1996; 25: 933-40.

40. [40] Shaib YH, El-Serag HB, Davila JA, Morgan R, McGlynn KA. Risk factors of intrahepatic cholangiocarcinoma in the United States: a casecontrol study. Gastroenterology. 2005; 128: 620-6.

41. [41] Jing W, Jin G, Zhou X, et al. Diabetes mellitus and increased risk of cholangiocarcinoma: a meta-analysis. Eur J Cancer Prev. 2012; 21: 24-31.

42. [42] Zhang LF, Zhao HX. Diabetes mellitus and increased risk of extrahepatic cholangiocarcinoma: a meta-analysis. Hepatogastroenterology. 2013; 60: 684-7.

43. [43] Chang JS, Tsai CR, Chen LT. Medical risk factors associated with cholangiocarcinoma in Taiwan: a population-based case-control study. PLoS One. 2013; 8: e69981. 
44. [44] Murphy G, Michel A, Taylor PR, et al. Association of seropositivity to Helicobacter species and biliary tract cancer in the ATBC study. Hepatology. 2014; 60: 1963-71.

45. [45] Welzel TM, Mellemkjaer L, Gloria G, et al. Risk factors for intrahepatic cholangiocarcinoma in a low-risk population: a nationwide casecontrol study. Int J Cancer. 2007; 120: 638-41.

46. [46] Hsing AW, Gao YT, Han TQ, et al. Gallstones and the risk of biliary tract cancer: a population-based study in China. Br J Cancer. 2007; 97: 1577-82.

47. [47] Genctoy G, Ayidaga S, Ergun T, Lakadamyali H, Erbayrak M, Sezer S. Increased frequency of gallbladder stone and related parameters in hemodialysis patients. Turk J Gastroenterol. 2014; 25: 54-8.

\section{Figures}

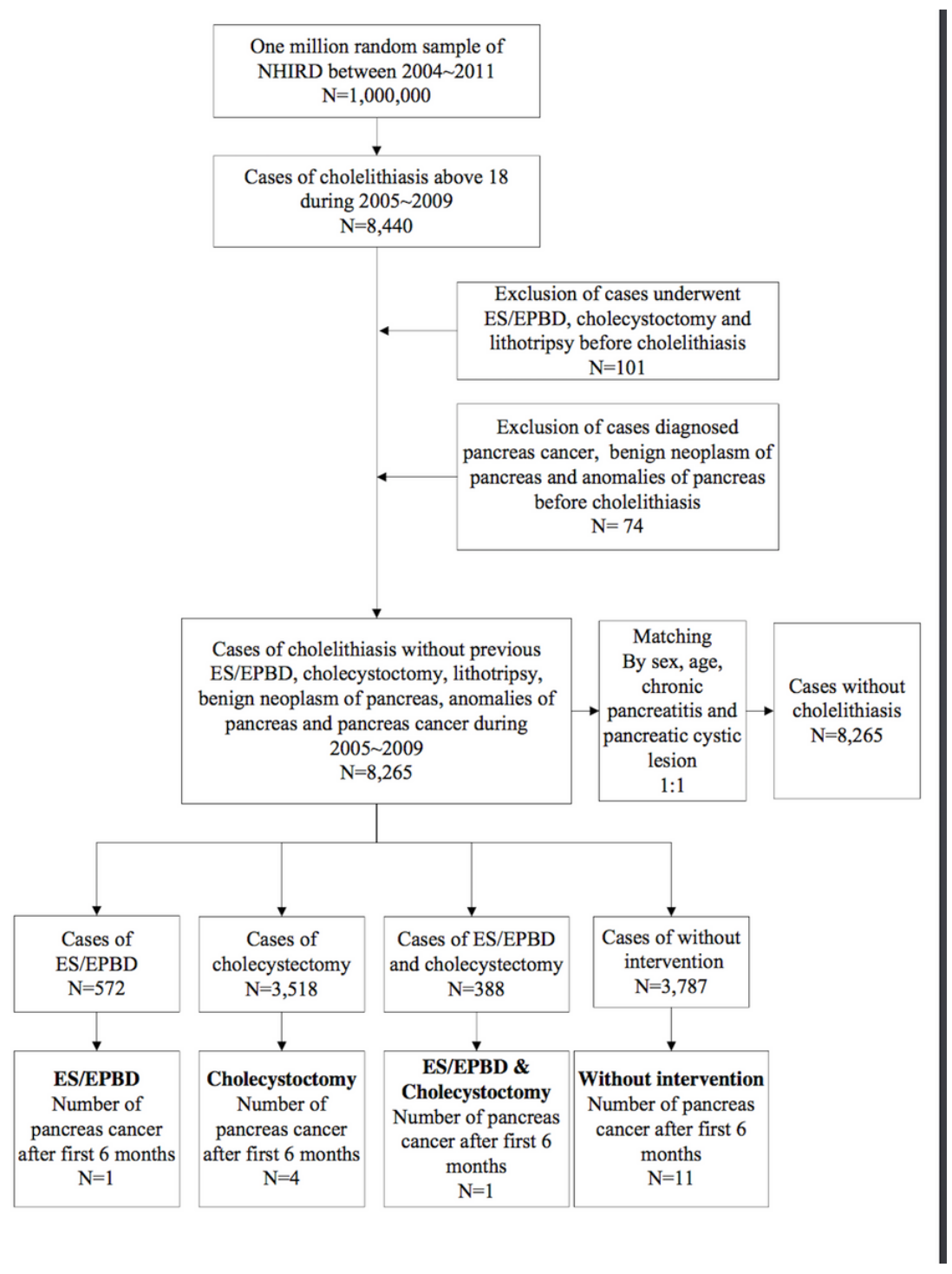

Figure 1

Flow chart for case selection from a database of one million nationwide representatives in Taiwan NHIRD = National Health Insurance Research Database, ES= endoscopic sphincterotomy, EPBD= endoscopic papillary balloon dilatation 

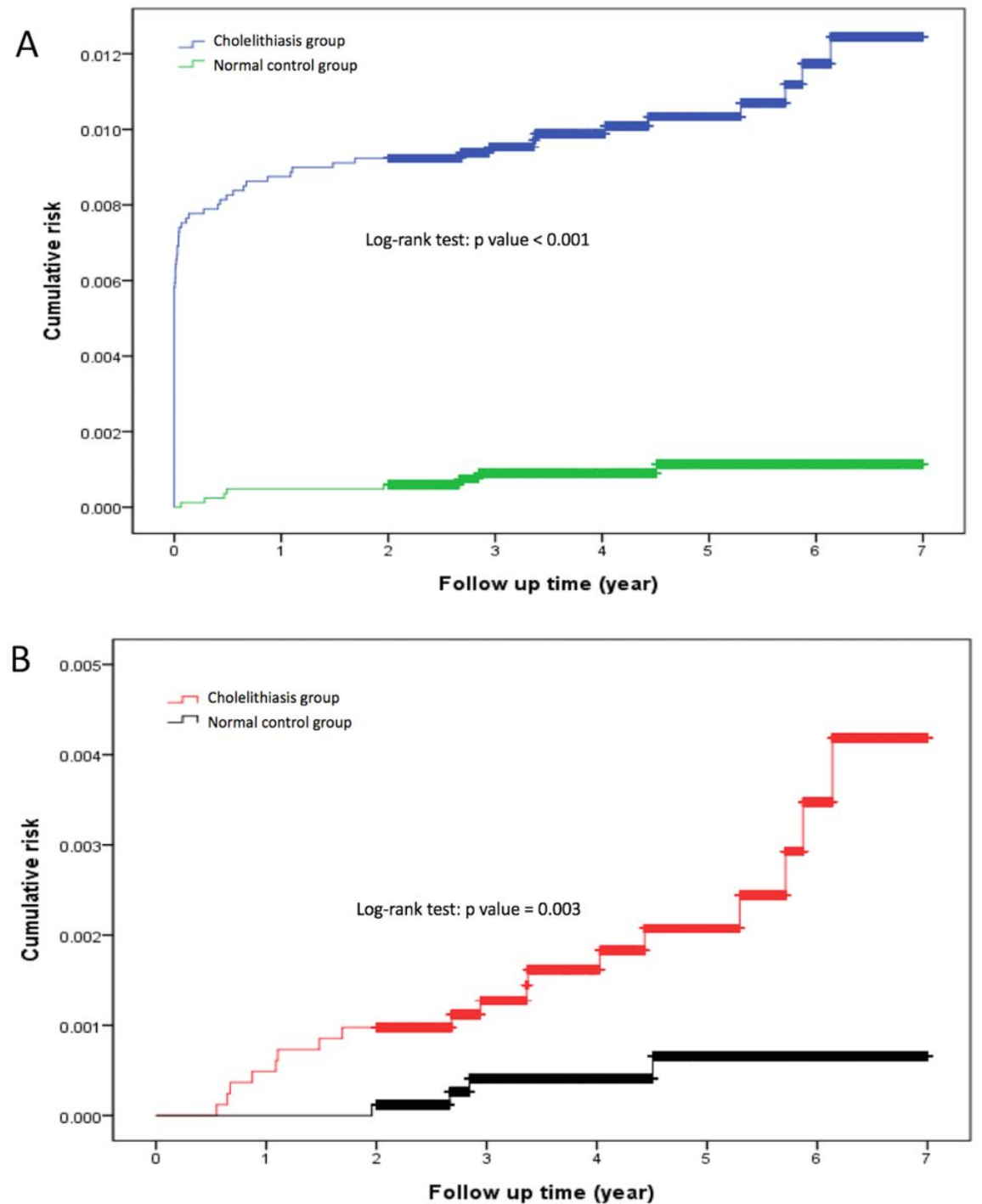

Figure 2

Pancreatic cancer risk (Panel A) and subsequent pancreatic cancer risk (Panel B) in the cholelithiasis group and control group 


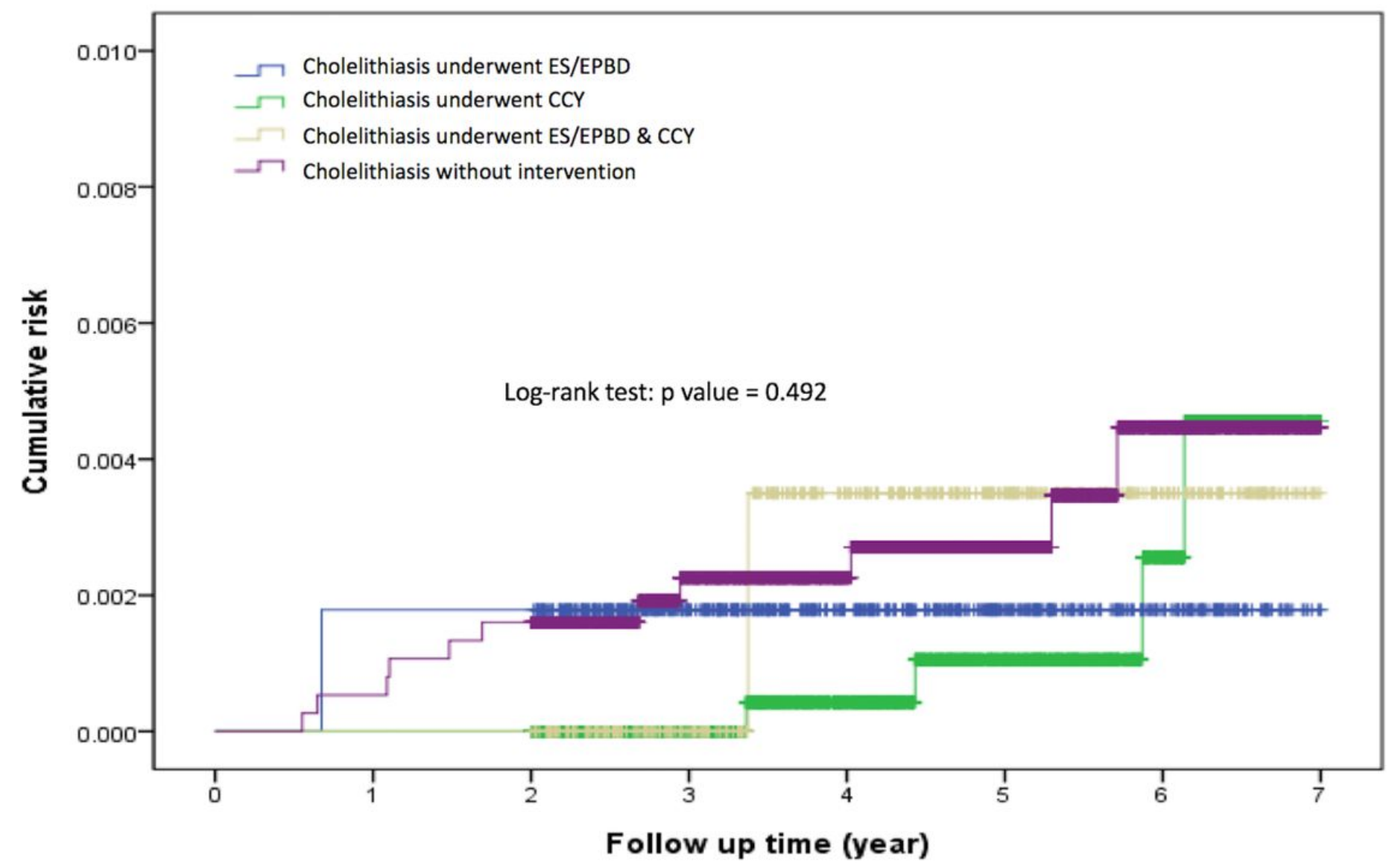

Figure 3

Cumulative risk for subsequent pancreatic cancer in the ES/EPBD, CCY, ES/EPBD \& CCY, and no-intervention group

\section{Supplementary Files}

This is a list of supplementary files associated with this preprint. Click to download.

- COlallauthors.1090407.pdf 